\title{
BACK TO THE BASICS: ELECTION INTEGRITY AS A EU ACCESSION CRITERIA FOR THE WESTERN BALKAN COUNTRIES
}

\author{
Jasmina Dimitrieva* \\ "University "Goce Delčev" of Štip (Republic of North Macedonia), Faculty of Law \\ (Jasmina.Dimitrieva@ugd.edu.mk; jasdim777@gmail.com)
}

\begin{abstract}
The Global Commission on Election, Democracy and Security defines election integrity as "election that is based on the democratic principles of universal suffrage and political equality as reflected in international standards and agreements, and is professional, impartial, and transparent in its preparation and administration throughout the electoral cycle". Elections with integrity are the key to preserving stability, peace and security not only at a national, but also at European level. The perspectives of the EU integration of the Western Balkans have been continuously viewed through the lens of the European security and stability. From the viewpoint of election integrity, the 1993 Copenhagen accession criteria require from the candidate countries to achieve stability of institutions guaranteeing democracy and the rule of law. The Western Balkan countries are experiencing a long-time struggle to satisfy the said EU democratic criteria. The paper aims to shed light on the 1993 Copenhagen criteria with respect to the obligation to conduct elections with integrity and discusses the EU support modalities for ensuring election integrity in the Western Balkans, as well as synergies created with other regional organizations in this regard. The paper concludes that regardless of the EU integration perspective of the Western Balkan countries, the citizens of the region deserve elections with integrity comparable to those of the EU countries.
\end{abstract}

Keywords: Copenhagen Criteria, Election Integrity, Election Standards, Western Balkans. 


\title{
KTHIM NË ELEMENTET BAZË: INTEGRITETI I ZGJEDHJEVE SI NJË KRITER PËR PRANIMIN E VENDEVE TË BALLKANIT PERËNDIMOR NË BE
}

\author{
Jasmina Dimitrieva* \\ "Universiteti “Goce Delčev” i Štip (Republika e Maqedonisë së Veriut), Fakulteti i Drejtësisë \\ (Jasmina.Dimitrieva@ugd.edu.mk; jasdim777@gmail.com)
}

\begin{abstract}
Abstrakt
Komisioni Global për Zgjedhjet, Demokracinë dhe Sigurinë e përcakton integritetin e zgjedhjeve si "zgjedhje të cilat bazohen në parimet demokratike të së drejtës universale të votës dhe barazisë politike siç reflektohet në standardet dhe marrëveshjet ndërkombëtare dhe është profesional, i paanshëm dhe transparent në përgatitjet dhe administrimin e tyre gjatë gjithë ciklit elektoral”. Zgjedhjet me integritet janë çelsi i ruajtjes së stabilitetit, paqes dhe sigurisë, jo vetëm në nivel kombëtar por edhe evropian. Perspektiva e integrimit të vendeve të Ballkanit Perëndimor në BE është parë gjithmonë nëpërmjet lenteve të sigurisë dhe stabilitetit evropian.

Nga pikëpamja e integritetit të zgjedhjeve, kriteret e Kopenhagenit 1993 për aderimin në BE, kërkojnë nga vendet kandidate që të arrijnë qëndrueshmërimë e institucioneve duke garantuar demokracinë dhe sundimin e shtetit të së drejtës. Vendet e Ballkanit Perëndimor po përjetojnë një betejë të gjatë për të plotësuar kriteret demokratike të kërkuara nga BE. Ky punim ka për qëllim të hedhë dritë mbi kriteret e Kopenhagenit të vitit 1993 lidhur me detyrimin për të mbajtur zgjedhje me integritet dhe diskuton mbi mënyrat e mbështetjes së BE-së për sigurimin e integritet të zgjedhjeve në Ballkanin Perëndimor, si edhe sinergjitë e krijuara me organizata të tjera rajonale në këtë 16spect. Punimi arrin në përfundimin se, pavarësisht perspektivës së Ballkanit Perëndimor në BE, qytetarët e rajonit meritojnë zgjedhje me integritet dhe të krahasueshme me ato të vendeve të BE-së.
\end{abstract}

Fjalë kyçe: kriteret $e$ Kopenhagenit, integriteti $i$ zgjedhjeve, standardet $e$ zgjedhjeve, Ballkani Perëndimor.

\section{Introducing Election Integrity Concept}

Election integrity is defined as "(...) elections based on the democratic principles of universal suffrage and political equality as reflected in international standards and agreements, and is professional, impartial, and transparent in its preparation and administration throughout the election cycle" (1). While elections with integrity are often used as a synonym for the paradigm of "free and fair" multi-party elections, the election integrity puts emphasis on the rule of law principle in elections and protection of active 
and passive election rights. The basic message is that all processes implemented in the election cycle must be honest and not corrupt.

While elections with integrity are a foundation of a democratic political system, they cannot be considered a synonym for democracy. In some instances, elections only enable liberalization of election outcomes. The voters have a choice to elect public officials from one or another dominant political party, who may not be knowledgeable about good governance and interested in defining and protecting public interests. Poverty, corruption, organised crime and ignorance might be used to defraud election process, restrict human rights and freedoms and perpetuate a viscous cycle of social wrongs even for future generations. Elections without integrity and untrustworthy governance will be resulting in a diminished public confidence in democratic institutions and a loss of trust in the rule of law.

Therefore, elections with integrity, as a central feature of the contemporary democracies, are indispensable for facilitating stability, peace and security not only at national, but also at European level. The European integration perspective of the Western Balkans remains heavily entangled with the security considerations of the EU, as well as of its members states. One does not need looking further than what has been happening in the region since the last decade of the last century, the terrible wars and conflicts in the former Yugoslavia, organised crime and massive migration flows through the Western Balkan route towards EU. As the EU High Representative for Foreign Affairs and Security Policy/Vice-President of the European Commission Josep Borrell put it: "The European Union is not complete without the Western Balkans. A credible enlargement policy is an investment in peace and security for the whole of Europe, even more so in times of increasing global challenges" (2).

Election integrity in the Wester Balkans should be at heart of the security considerations of the EU and of its individual member states. Elections attract attention as they determine the political dimension in the Western Balkans, a region that is still straggling to put into practice the concepts of democratic governance and the rule of law.

\section{The 1993 Copenhagen Criteria and Elections with Integrity}

The Copenhagen criteria are the gates that Western Balkan candidate countries must open in order to enter EU. These criteria were defined by the European Council in Copenhagen in 1993 (3).

From the viewpoint of election integrity, the most important political criterion reads as follows: "the candidate country has achieved stability of institutions guaranteeing democracy, the rule of law".

The wording of the Copenhagen criteria is broad and general, and thus may be leading to various interpretations (4). However, it is clear that elections are an intrinsic element of democracy, allowing for a peaceful transfer of power to the majority preferred election candidate. Moreover as Tanya Marktler put it: "[e]lections taking place in all of the applicant countries, have been a major focus of these combined principles (...) referring to democracy and rule of law" (5).

According to Ronald Janse, the European Commission monitoring and evaluating the progress of the candidate countries towards EU considered that "regular elections conducted on the basis of secret ballots, universal adult suffrage, and a competitive, multiparty political system were essential. But the Commission went beyond a minimalist 
understanding of democracy, often called "electoral democracy"' (6). The Commission during the enlargement process also examines other connected rights, such as freedom of expression and political association (7).

Considering the meagre content of the Copenhagen criteria, the question arises as to the election requirements that need to be satisfied by the candidate countries. There is no single European treaty on election standards in the Euro region. Therefore, to define the election integrity requirements in view of the Copenhagen criteria, firstly the examination of the EU election rules is warranted.

Turning to the EU election rules, it is clear that passive and active election rights are fundamental human rights (8). In addition to article 39 of the Charter on Fundamental Rights, legal bases in the primary legislation are to be found in article 14 of the Treaty on European Union (TEU); and articles 20, 22 and 223 of the Treaty on the Functioning of the European Union (TFEU). The secondary legislation encompasses the 1976 Act Concerning the Election of the Members of the European Parliament by Direct Universal Suffrage as amended in 2002 (9). The election principles that transpire from the above legislation encompass the universality of the vote, protection of passive election right, direct election of the European Parliament - body with legislative powers, elections on regular intervals with free and secret ballot based on non-discrimination. The highlight is placed on the integrity of elections, albeit implied, considering the overreaching principle of the rule of law in the EU legislation. With respect to election legislation, the general EU principles of legal certainty, legitimate expectation, transparency and accessibility of legislation, stemming from the rule of law principle, are applicable (10). The observance of the above principles is indispensable as a safeguard of the election integrity.

Election standards of another European regional organization, that is, the Council of Europe $(\mathrm{CoE})$ are also important in the context of the EU enlargement and the Copenhagen criteria. Paragraph 10 of the 2007 Memorandum of Understanding between the Council of Europe and the European Union re-affirms the Council of Europe standards as a continuous benchmark for observing democracy and the rule of law. Although EU has not yet joined the CoE's European Convention on Human Rights (ECHR), article 3 of Protocol no. 1 of the ECHR, that is guaranteeing free and fair elections of a legislature, has entered into force for all EU members. In addition, the EU Charter and the ToL reaffirm the fundamental value of the ECHR in the human rights arena (11).

National election rules also apply with respect to the elections of the European Parliament. In this regard, all EU member states are OSCE participating states and they conduct their elections in line with the OSCE political commitments (12). The elections of the European Parliament were assessed twice by the OSCE Office for Democratic Institutions and Human Rights (ODIHR) in 2004 and in 2009 against the OSCE election commitments (13). In 2009, the ODIHR election assessment mission concluded that in spite of the common EU principles and individual rights related to elections, there was a diversity of national rules and practices in the conduct of the European Parliament elections. The above assessments add to the argument that the examination of the OSCE political commitments is warranted in the context of the applicable election standards when elections in the Western Balkans are at stake.

\section{Elections with Integrity in Article 3 of Protocol no. 1 of the CoE ECHR}


Ratifying states of the CoE's ECHR article 3 of Protocol no. 1 must hold free, periodic and secret election of a legislature (14). Elections must be organised with integrity, which ad minimus requires effective protection of election candidates and voters from intimidations and threats, and punishment of any attempts to rig elections (15). The countries enjoy a wide margin of appreciation in the election context. Election passive and active rights are qualified rights (16). However, any interference with election rights must be lawful, in accordance with the rule of law principle (17). The interference must pursue a legitimate aim, such as protection of the rule of law principle, of national security and crime prevention, and must be justified. The interference must meet a societal necessity, or a pressing social need. The European Court of Human Rights (ECtHR) conducts a balancing exercise between the individual election right and protection of the public good. The interference complained of must not be disproportionate, or arbitrary to the extent that it thwarts the free expression of the will of the people (18). An arbitrary interference is the unjustified one, imposed as a result of abuse of power, and/or in unfair procedure.

\subsection{Election fraud and remedies}

In a number of Azerbaijani cases, the applicants complained about inadequate and ineffective legal remedy capable of correcting the wrongs caused by a number of election irregularities, which affected the election rights and election results (19). The ECtHR found a violation of article 3 of Protocol no. 1 to the ECHR. In particular, not only the election commission left the applicant's complaint unexamined, but the ensuing appeals were rejected for purely formalistic reasons, and thus, the appeals were left unexamined in substance.

The ECtHR underscores that adequate and effective legal remedies in election context are of vital importance for a vibrant and sustainable democratic society and for protecting individual election rights. The ECtHR re-affirms that there is no true democracy without adherence to the rule of law doctrine. Moreover, the rule of law, one of the fundamental principles of a democratic society, is intrinsic to the ECHR articles and protocols (20). Although the complaints about the unfairness of judicial proceedings related to elections are outside of the scope of article 6 of the ECHR guaranteeing free and fair trial, the ECtHR requires a thorough and effective investigation and impartial and objective examination of election-related cases by an impartial election administration under very article 3 of Protocol no. 1 of ECHR. ECHR makes an explicit reference to the lawfulness of the measures taken by the ratifying State. Elections with integrity are the right channel to instal a rightful election winner in a public office, the one who is considered trustworthy by the voters to occupy a public office. Furthermore, elections must reflect, or not run counter to, the concern to maintain the integrity and effectiveness of an election procedure aimed at identifying the will of the people through universal suffrage (21).

\subsection{Relevant ECtHR Case-Law and the Western Balkan Countries}

There are ECtHR judgments and decisions deciding on alleged violations of article 3 of Protocol no. 1 with respect to the Western Balkan countries. In a well-known judgment of Sejdic and Finci v. Bosnia and Herzegovina $(\mathrm{B} \& \mathrm{H})$ the ECtHR established that B\&H infringed upon the ECHR rights of the election candidates, affiliated to the smaller 
communities. They were discriminated against, as they were barred from standing in presidential and legislative elections for the House of Peoples on the ethnic ground (22). In the ECtHR case Baralija v. $B \& H$, the applicant complained that she has been discriminated against as no local elections were held in Mostar since 2008, which infringed upon her passive and active election rights (23). The complaint was examined under article 1 of Protocol no. 12 of ECHR prohibiting discrimination in general terms. The Court established a violation, holding that $\mathrm{B} \& \mathrm{H}$ failed to fulfil its positive duty to hold democratic elections in Mostar, without providing an objective, reasonable and sufficient justification in this regard. Difficulties in reaching a power-sharing decision, which would unblock the elections in Mostar was not deemed a sufficient, objective and reasonable justification for the difference in treatment based on residence.

In 2016, in the judgment Paunović and Milivojević v. Serbia, the ECtHR ruled on the practice of political parties to require and use undated resignation letters signed by their elected party members, in order to remove those members from office at any time and against their will (24). The ECtHR took the view that, even though the resignation letter would be submitted by the party, only the Parliament was entitled to withdraw a seat. It was therefore the State, which deprived the Member of the Parliament (MP) of the seat by accepting the resignation. The application of an MP who had lost his/her seat was thus admissible ratione personae. The ECtHR found that the impugned practice was at odds with domestic law, which required such resignations to be submitted by the MP in person, and established a violation of article 3 of Protocol No. 1. The ECtHR also took into consideration the Opinion of the European Commission for Democracy through Law (Venice Commission) on the Constitution of Serbia adopted at its $70^{\text {th }}$ plenary session in 2007. The Venice Commission considered it a serious violation of the freedom of an MP to express his/her view on the merits of a proposal or action, if he or she may put the MPs' mandate at disposal of the political party, which had nominated him/her (article 102 of the Serbian Constitution). The MPs may be forced to resign if they do not agree with their party leadership strategy or if they change their political affiliation. In such a way, excessive power was concentrated in the hands of the party leaderships.

\section{Election Integrity in the OSCE/ODIHR Election Standards}

The election cycle is composed from pre-election, election and post-election periods (25). During each period of this cycle important OSCE election commitments must be observed to maintain the election integrity. Bearing in mind the election integrity requirement, the highlighted OSCE political commitments encompass the following (26).

In the pre-election period, the election law must embody the requirement for the elections to reflect the free will of the people, and to be held periodically. Universality of the vote, non-discrimination and equal suffrage must be stipulated in the law. The election law must be clear and coherent, any amendments to the election law must be adopted in good time before elections, so that the candidates and voters are well aware of the election rules in time of the elections. During the pre-election phase, adequate and effective remedies must be available for voters' registration (27).

In the election period, the states must ensure that no candidate, especially the ones from the ruling parties, gains unlawful and unfair advantage over other. Elections must be free from any violence or pressure (28). Security of voters, candidates and election material must be ensured. The candidates should be able to carry out their campaigning freely, 
while political pluralism must be protected (29). The rules on financing and media access must be clear and foreseeable (30). Effective remedy for the election processes must be available to candidates and voters.

Post-election phase must ensure effective and timely resolution of election disputes. The criminal-law remedies must be effective enough to end impunity in election-related cases (31).

\subsection{OSCE/ODIHR - The Observation Champion in the Western Balkans}

OSCE is mandated to observe elections in the OSCE region. Election observation enhances election process, and its integrity. What do recent election observation reports say for the Western Balkans? When looking at the recent reports the first what catches the eye is that most of the recommendations from previous election observation reports remained unaddressed by the state authorities. Although the recommendations are repeated over and over again, the authorities of the Western Balkan countries remain inactive.

There are election observation recommendations that can be found in most of the ODIHR reports with respect to Western Balkans. Summarized findings include misgivings with respect to the stability of elections laws, when they were amended hastily, without envisaging sufficient implementation period for the parties and election administration, which adversely affects their implementation. Inaccurate voters' lists were pointed out as a weakness that needs to be addressed by the authorities. Media coverage was usually favoring the ruling party or few major parties, without providing in-depth analysis of their political platforms. Campaign financing usually finds its way in the election observation reports due to insufficiently transparent campaign finding and abuse of state resources. Votes' buying and voters' intimidation was also among election irregularities highlighted in the election observation reports (32).

\section{EU, Western Balkans and Election Integrity: Never Ending Story?}

Generally speaking, the pace of EU integration of the Western Balkan countries is slow. The Western Balkan countries are struggling with their ability to satisfy the EU democratic criteria and ensure the stability of democratic institutions and the rule of law. This is the one side of the EU integration coin regarding Western Balkans. The other side of the EU integration coin is the EU absorption capacity with respect to these countries, stipulated in the 1993 Copenhagen (accession) criteria (33).

Regardless of the EU absorption capacity, the voters from the Western Balkan countries must be afforded elections with integrity, as envisaged in the international documents containing legally-binding election standards and political commitments.

What is EU doing to ensure election integrity in the Western Balkans, and thereby increase the legitimacy and credibility of the election process? The activities can be categorized as follows: 1. Commission's monitoring reports of the progress of the candidate countries, 2. EU election observations, 3. Election reform support programmes, and 4. Political dialogue and diplomacy.

\subsection{Progress Monitoring on The Path Towards EU}


First and the most important EU activity in this regard is the monitoring of the countries' progress along the EU path, which is more effective, when accompanied by a credible enlargement process with clear criteria. Election developments are always mentioned in the Commission's progress reports in the part devoted to the political criteria. The Commission is also underscoring any recommendations from the previous annual report, which remained unaddressed. The lack of implementation of the judgment of Finci and Sejdic v. B\&H is noted in the Commission's report addressed to this country (34). This report further highlights a lack of progress in improving election framework in line with European standards and ensuring transparency of political party financing. The Amendments adopted in July 2020 should enable holding of local elections in Mostar for the first time since 2008 (35).

The above also indicated the interplay of the EU with the other two European organizations, that is, CoE and OSCE/ODIHR. The Commission keeps abreast of the enforcement of the ECtHR judgments and follows on the election observation reports of the OSCE/ODIHR. These three organizations are speaking in one voice, when elections are at stake.

The Commission's task is also to keeps the EU Council and European Parliament informed throughout the process, by way of regular reports, strategy papers and clarifications on conditions for further progress.

\subsection{Election Reform Support Programmes}

Support for election reform provided by EU demonstrates even better this interplay between the European regional organizations in the election sphere. EU funds programmes in view of providing a meaningful follow-up to the recommendations set out in the OSCE/ODIHR election observation reports addressed to the Western Balkan countries. These support programmes are mainly funded by the Instrument for Pre accession Assistance.

The EU election reform support programme "EU4Democracy: Support to election reform in the Western Balkans Horizontal support programme" contributes towards strengthening democratic institutions and processes in the Western Balkans (36). The aim is to bring elections in compliance with OSCE commitments and other international obligations and standards for democratic elections. This new programme builds on the positive results of previous OSCE/ODIHR regional elections reform support programme funded by EU, and implemented by OSCE/ODIHR "Support to Elections in the Western Balkans" from 2017 to 2020, which was also focusing on supporting the compliance with the OSCE/ODIHR recommendations.

The election reform support programme is fully in line with the 2018 Western Balkans Strategy that stresses the importance of free and fair elections and proper implementation of recommendations of election observation missions (37). Increased knowledge and skills of the stakeholders, increased awareness of the election reforms of the beneficiaries and exchange of best practices among the Western Balkan countries are among the objectives of the upcoming election reform support programme. A brief overview of the recent election observation reports of the respective countries discloses the need for the election reform support programme to address the following (38): 
1. A declining confidence in the impartiality and independence of election management bodies (EMBs), due to their limited capacities, inadequate legal framework, insufficient transparency of the election processes and undue influences.

2. Concerns about the accuracy of voter lists and voter registration processes, not being sufficiently coordinated with the population registers and inadequate remedies for the voters who have been denied to cast a vote.

3. Restricted freedom of expression manifested in inequitable access to media, insufficient legal safeguards, incrimination of defamation, a lack of effective, independent and autonomous media regulatory power.

4. Electoral violence and intimidation.

5. Campaign financing rules, disclosure, monitoring and regulatory capacities which do not fully enable transparency and accountability of electoral campaigns.

6. Ineffective election dispute adjudication, due to limited capacity and dependency of the election dispute resolution bodies.

In view of the above, the upcoming election reform support programme will address the following thematic areas: i) effectiveness of election management bodies (EMBs); ii) voter lists and voter registration processes; iii) capacity and know-how of media regulatory bodies and media coverage during elections; iv) election campaign rules; and v) capacity and know-how of election dispute resolution bodies.

Judging by the practice so far, in co-ordination with OSCE/ODIHR, the EU will, as necessary, engage with host authorities to secure their cooperation and push the realization of the election reform agenda. EU acts as a leverage to push for implementation of the OSCE/ODIHR election reform recommendations.

\subsection{EU Observes Elections}

Election observation is a vital EU activity aiming to promote democracy, human rights and the rule of law, worldwide. It reinforces the key EU foreign policy objectives, strengthens democratic institutions, public confidence in election processes and helps deter election fraud and curb violence.

However, the EU does not regularly deploy election observation missions in the Western Balkans, except for Kosovo, which used to rely heavily on the OSCE Mission in Kosovo for organizing and observing the elections. In 2019, from all of the Western Balkan, the EU only deployed its election observation mission to Kosovo for early national elections and presented its recommendations:

There are recurring systemic problems with the election process. For instance, lack of clear provisions on challenging results at all levels, issues concerning the accuracy of the voter list, inadequate campaign finance regulation and oversight, and many others. These problems need to be urgently addressed, considering also the efforts already taken by the Assembly's ad-hoc parliamentary committee, in order to bring Kosovo fully in line with international standards for democratic elections.

concluded Viola von Cramon-Taubadel, the member of the European Parliament and Standing Rapporteur for Kosovo. 
In this context, it is important to mention the European Parliament's Democracy Support and Election Coordination Group, which is observing elections in cooperation with ODIHR. As a rule, other election groups join the ODIHR election observation mission, but they only observe elections on the election day. As an example, in 2020, the President of the European Parliament David Sassoli announced observation of parliamentary elections in Montenegro (39). The Western Balkans is among the priorities of the European Parliament's Democracy Support and Election Coordination Group, according to this group's annual programme.

\subsection{Facilitating Political Dialogue and Supporting Decision-Making Process}

The EU is also involved in resolving difficult situations in the countries, which might warrant early elections. The power of the EU in the Western Balkans is used as a leverage to push for reforms and implementation of recommendations and decisions of the regional organizations. It supports the work of experts and putting into practice their technical advice by assuring EU presence and political leverage to the process and its outcomes. EU is also called upon to resolve the most difficult political processes in the country, for example a facilitation of a dialogue between opposing social forces, and/or forging a deal to overcome social conflicts, the cycles of stagnation, and to avoid sliding back into captured state. With no doubts EU, is counted among the strongest and the most powerful political external actors in the Western Balkans. The leverage that the enlargement process provides to EU as a supra-national organization is unprecedented.

\section{EU Preparedness for the Western Balkan Countries}

However, EU was aware even in 1993, that the transition from socialism to democratic governance of the ex-socialist countries and the enlargement process would bring not only economic costs, but also many other political, security, international, regional and legal challenges. Therefore, the 1993 Copenhagen criteria clearly set out that regardless of the fulfilment of the criteria of the candidates, the absorption capacity of the EU can be a showstopper for a country wishing to join EU. This criterion is also quite broad and open to interpretations, so it is not clear how the EU decides about its absorption capacities when different countries are involved. Whis ones are absorbable, and which ones are not? It may be that the EU absorption capacity is directly linked with the number of vetoes a candidate country receives from EU member states when trying to pass the EU membership gates. Regional conflicts and unresolved issues are a wake-up call for the Western Balkan countries dreaming of becoming a part of EU.

The EU absorption capacity appears to play a role in the approximation of the whole Western Balkans and separately for each of the countries situated in this region. If the enlargement were only a technical process depending on the fulfillment of the EU enlargement criteria, there would not have been a need for such a criterion in the Copenhagen criteria. If the problems are structural and depending on complex institutional reform, that could only delay the enlargement, but not terminate the process. The EU should be more transparent with respect to its absorption capacity criterion, as such a showstopper may create negative effects for the democratic order and the rule of law in the countries wishing to join the EU. 


\section{What Is Done and What Needs to Be Done to Ensure Stability of Democratic Institutions and the Rule of Law in the Western Balkans?}

A desk review and a review of the inventory of relevant reports reveal positive sides and threats with respect to the on-going process of working towards fulfilling the relevant Copenhagen criteria by the Western Balkan countries. The negative outcomes which appeared during the transition process indicate a number of threats and challenges that the Western Balkan countries have to meet and overcome in order to pass over to the other side of prosperous and sustainable democratic societies. For example:

-As to the elections, authors speak about liberalization of election outcomes, when elections enable a change of the political actors leading the country, but no real sustainable democratic changes are materialized in the society. Regular elections cannot be considered sufficient for a society to be considered democratic, as their effect could be a sustainable survival of competitive authoritarianisms (40). Slipping into competitive authoritarianism is a real threat to the political orders of the Western Balkan countries.

-Organised crime can become the biggest threat to the survival of a sustainable democratic order in the Western Balkans. The disintegration process, recent wars and conflicts opened a bigger window of opportunity for the organized crime gangs from the region and abroad. According to the EU Commission's reports, trafficking in weapons, persons, arms, waste dangerous to the environment exists in the region. Large profits are earned by criminal gangs, that can be used for corruption, illegal deeds and for putting pressure on the regional political elites, and thus perpetuate anarchy and destroy the rule of law, with aim to produce and maintain an environment conducive to criminal activities (41). The Balkan strategy also warns about the existence of the organised crime and corruption in the region (42).

On a positive side, the Western Balkan countries, have been practicing a multi-party democracy for decades. There is a plurality of political choice, regular national and local elections and many years of electoral practice observed by independent election observers. The election laws are slowly and gradually improving. The voters are not so naïve any longer, they are much more informed about the offers and programmes of the political candidates, and have developed capacities to evaluate the job of the Government. The citizens are much more aware about their human rights and civil liberties. There is an increasing meaningful representation of women and ethnic minorities in the public affairs. A positive outcome of the process is that there has been a collective learning coming from practicing democracy, participating in elections and striving to live the rule of law principle in reality.

\section{Conclusions}

From the above discussion the following conclusions can be draw.

Elections and stability of democratic institutions from the Copenhagen criteria are not one and the same, but elections with integrity are sine qua non for the development and stability of the democratic system in the Western Balkans, as required by the Copenhagen criteria. The election integrity matters first and most for the people of the Western Balkans who do not deserve less than elections in compliance with EU election standards, regardless of the EU's absorption capacity, and the enlargement outlook. 
Nurturing legal and political democratic culture is the key to sustainability of all the efforts invested into elections with integrity in the Western Balkans. Democratic legal and political culture must take a permanent hold to counterbalance aggressive behaviors based on corruption, unfairness and exploiting of vulnerabilities. The rule of law must be uphold in any possible way, as there cannot be elections with integrity without the rule of law principle translated into practice.

\section{References}

(1) VV. AA., Deepening Democracy: A Strategy for Improving the Integrity of Elections Worldwide, September 2012, available at www.idea.int/sites/default/files/publications/deepening-democracy.pdf. (2) Borrell: Europe is Not Complete Without the Western Balkan, in European Western Balkans, 7 October 2020, available at www.europeanwesternbalkans.com/2020/10/07/borrell-europe-is-not-completewithout-the-western-balkan/.

(3) European Council, Conclusions of The Presidency, SN 180/1/93 REV 1, Copenhagen, 21-22 June 1993.

(4) T. MARKTLER, The Power of the Copenhagen Criteria, in Croatian Yearbook of European Law and Policy, Vol. 2, 2006, pp. 343-363.

(5) Ibid.

(6) R. JANSE, Is the European Commission a CREDIBLE guardian of the Values? A Revisionist Account of the Copenhagen Political Criteria During the Big Bang Enlargement, in International Journal of Constitutional Law, Vol. 17, No. 1, 2019, pp. 43-65.

(7) Ibid .

(8) Charter on Fundamental Rights of the European Union, article 39.

(9) Council Directive 93/109/EC of 6 December 1993, laying down detailed arrangements for the exercise of the right to vote and stand as a candidate in elections to the European Parliament for citizens of the Union residing in a Member State of which they are not nationals, in OJ L 329 of 30 December 1993, pp. 34-38; amended by the Council Directive 2013/1/EU of 20 December 2012, amending Directive 93/109/EC as regards certain detailed arrangements for the exercise of the right to stand as a candidate in elections to the European Parliament for citizens of the Union residing in a Member State of which they are not nationals, in OJ L 26 of 26 December 2012, pp. 27-29.

(10) P. CRAIG. G. DE BURCA, EU Law, 2003, pp. 358-395.

(11) Treaty of Lisbon, 2007, article 6, paragraph 3 and Charter on Fundamental Rights of the European Union, article 52.

(12) Organization for Security and Cooperation in Europe.

(13) OSCE/ODIHR, Observation of the European Parliament Elections, available at www.osce.org/odihr/elections/eu.

(14) Protocol No. 1 of ECHR, article 3 reads as follows: "[t]he High Contracting Parties undertake to hold free elections at reasonable intervals by secret ballot, under conditions which will ensure the free expression of the opinion of the people in the choice of the legislature".

(15) D.J. HARRIS, M. O'BOYLE, C. WARBRICK, Law of the European Convention on Human Rights, London, 1995, pp. 19-21.

(16) ECtHR (Chamber), judgment of 1 July 1997, application nos. 18747/91, 19376/92, 19379/92, 28208/95 and 27755/95, Gitonas and others v. Greece, para. 39; ECtHR (Fifth Section), judgment of 30 June 2009, application nos. 35579/03, 35613/03, 35626/03 and 35634/03, Etxeberria Barrena Arza Nafarroako Autodeterminazio Bilgunea and Aiarako and Others v. Spain, para 48.

(17) ECtHR (Grand Chamber), judgment of 30 March 2004, application no. 74025/01, Hirst (No. 2) v. the United Kingdom.

(18) ECtHR (Plenary), judgment of 2 March 1987, application no. 9267/81, Mathieu-Mohin and Clerfayt, para 52; ECtHR, Gitonas and Others v. Greece, cit., para 39; ECtHR (Grand Chamber), judgment of 30 January 2007, application no. 10226/03, Yumak and Sadak v. Turkey.

(19) ECtHR (First Section), judgment of 30 September 2010, application no. 20799/06, Kerimova v. Azerbaijan. See also ECtHR, judgment of 10 April 2012, application no. 4641/06, Mammadov v. Azerbaijan (no. 2). 
(20) See, among many other authorities, ECtHR (Chamber), judgment of 25 June 1996, application no. 19776/92, Amuur v. France, para 5.

(21) ECtHR, Yumak and Sadak v. Turkey, cit., para. 109.

(22) ECtHR (Grand Chamber), judgment of 22 December 2009, application no. 27996/06, Sejdić and Finci v. $B \& H$.

(23) ECtHR (Fifth Section), judgment of 29 October 2019, application no. 30100/18, Barlija v. B\&H.

(24) ECtHR (Third Section), judgment of 24 May 2016, application no. 41683/06, Paunović and Milivojević v. Serbia.

(25) What is the Electoral Cycle?, in ACE. The Electoral Knowledge Network, available at www.aceproject.org/electoral-advice/electoral-assistance/electoral-cycle.

(26) OSCE, The Copenhagen Document, 1990, paras. 6 and 7 (which is different from the Copenhagen enlargement criteria); OSCE, The OSCE Human Dimension Commitments, 1 Thematic Compilation, 3rd edition, 2011, pp. 80-84; OSCE, Existing Commitments for Democratic Elections in OSCE participating states, 2003.

(27) OSCE/ODIHR, Handbook for the Observation of Voter Registration, 2012, pp. 28 and 55. See also OSCE/ODIHR, Statement of Preliminary Findings and Conclusions with respect to Armenian Presidential Elections, 2013, p. 2.

(28) Check as secondary resource: OSCE/ODIHR, Handbook for Domestic Election Observers (Macedonian translation), 2005, p. 16.

(29) For example, OSCE/ODIHR Final Report on Kazakhstan Early Parliamentary Elections, 2012, p. 27. (30) See, among others, OSCE/ODIHR, the Election Assessment Mission Report on Iceland, 2013, pp. 910.

(31) OSCE/ODIHR, Final Report on Kazakhstan, cit., 2012, pp. 18 and 28. Although not in Europe or Western Balkans, the report on Kazakhstan has been mentioned for better illustration of the OSCE standards in the election field.

(32) See the latest ODIHR election observation reports for Western Balkans, for example: ODIHR, Special Election Assessment Mission Final Report, Parliamentary Elections of Serbia, 7 October 2020; ODIHR, Limited Election Observation Mission Final Report, Parliamentary Elections of Montenegro, 30 August 2020; ODIHR, Special Election Assessment Mission Final Report, Early Parliamentary Elections of North Macedonia, 15 July 2020; ODIHR, Election Observation Mission Final Report, Presidential Election of North Macedonia, 21 April and 5 May 2019; ODIHR, Election Observation Mission Final Report, General Elections of $B \& H, 7$ October 2018.

(33) The Copenhagen accession criteria also contains a fourth criterion, which reads as follows: "[t]he capacity of the Union to absorb new Member States while maintaining the momentum of the European integration process."

(34) European Commission, Final Bosnia and Herzegovina 2020 Report, SWD (2020) 350, Brussels, 6 October 2020.

(35) See ECtHR, Barlija v. $B \& H$, cit.

(36) European Commission, EU4Democracy: Support to election reform in the Western Balkans Horizontal 2021-2027, available at www.ec.europa.eu/neighbourhood-enlargement/sites/default/files/ipa_2020-041818.08-mc-eu4democracy-electoral_reform.pdf.

(37) European Commission, Communication from the Commission to the European Parliament, the Council, the European Economic and Social Committee and the Committee of the Regions A Credible Enlargement Perspective for and Enhanced EU engagement with the Western Balkans, COM(2018) 65 final, Strasbourg, 6 February, 2018.

(38) See the latest ODIHR election observation reports for Western Balkans, for example: ODIHR, Special Election Assessment Mission Final Report, Parliamentary Elections of Serbia, cit.; ODIHR, Limited Election Observation Mission Final Report, Parliamentary Elections of Montenegro, cit.; ODIHR, Special Election Assessment Mission Final Report, Early Parliamentary Elections of North Macedonia, cit.; ODIHR, Election Observation Mission Final Report, Presidential Election of North Macedonia, cit.; ODIHR, Election Observation Mission Final Report, General Elections of B\&H, cit.

(39) Sassoli: Observing elections in Montenegro is a priority, in European Western Balkans, www.europeanwesternbalkans.com/2020/07/13/sassoli-observing-elections-in-montenegro-is-a-priority/.

(40) S. LEVITSKY, L. WAY, The Rise of Competitive Authoritarianism, in Journal of Democracy, No. 13, 2002, pp. 51-66. 
(41) See for example European Commission, Final Bosnia and Herzegovina 2020 Report, cit.; European Commission, Final North Macedonia 2020 Report, SWD(2020) 351, Brussels, 6 October 2020; M. LYMAN, G. POTTER, Organized Crime (Macedonian edition), Skopje, 2009, pp. 308-310.

(42) European Commission, A Credible Enlargement Perspective for and Enhanced EU engagement with the Western Balkans, cit. 